\title{
NORTH AMERICA'S LARGEST SHOREBIRD - HAVE YOU SEEN IT?
}

ROSS D. DICKSON, \#303, 9510 - 79 Street N.W., Edmonton, AB T6C $2 R 9$ and GERARD W. BEYERSBERGEN, Canadian Wildlife Service, \#200, 4999-98 Avenue N. W., Edmonton, AB T6B 2X3

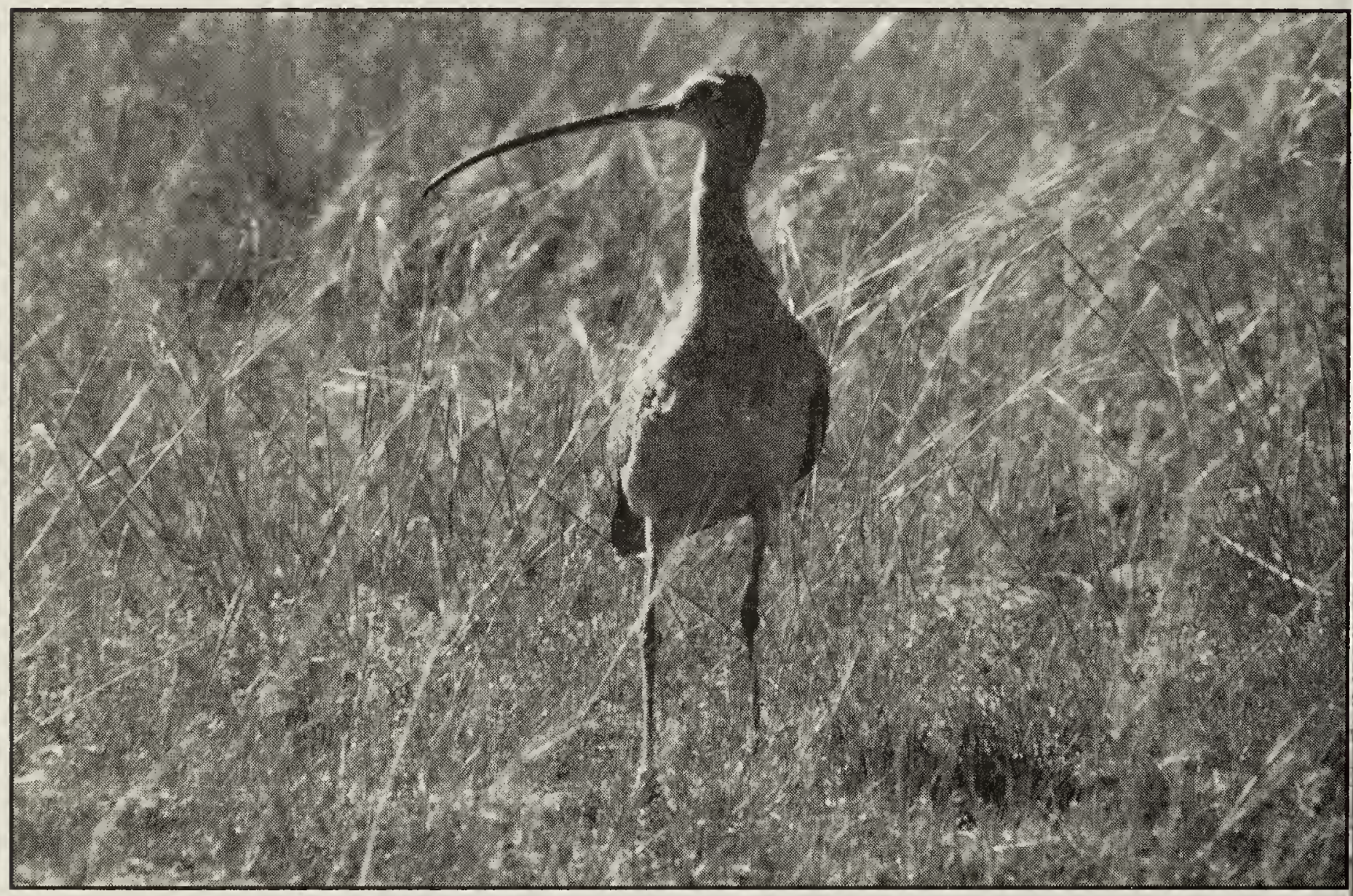

G.W. Beyersbergen

This shorebird is easily identified by its large size and long down-curved bill. Its arrival in western Canada each April is well-documented. Beyond this general information, there are few published Canadian-based accounts about the ecology, population status, or migration of the Long-billed Curlew (Numenius americanus). Whether you have observed one curlew, or a flock, we would like to receive your observation (see details in the last paragraph).

On 11 August 1997, the authors found several scattered groups of Long-billed Curlews feeding in a native prairie pasture beside Highway 36, west of Brooks, Alberta. We watched the birds for about 10 minutes, and each counted 82 curlews when they flushed due to highway traffic noise. The pasture showed evidence of recent grazing, with most grass height less than $10 \mathrm{~cm}$.

Large flocks of curlews in Canada are seldom reported in the literature. A Saskatchewan status report listed only four flocks of at least 100 birds; Ardath, Saskatchewan, 27 July 1980 (140+); Cypress Hills-Frenchman River, Saskatchewan, 19 August 1976 (at least 100); Medicine Hat, Alberta, 2 August 1920 (100); and Many Island Lake, northeast of Medicine Hat, 8 August $1920(100)^{7}$. Large spring records are recorded for Alkali Lake, British Columbia, 4 April 1968 (100), and, in the 
Lethbridge area (May Species Count), 28 May $1978(103)^{3,6}$.

Field biologists indicate recent sightings of curlew staging, prior to migration, may be both rare and spectacular. A flock of 120 Long-billed Curlews was observed on a gravel bar on the Bow River, NE of Hays, Alberta 7 July 1989 (U. Banasch, pers. comm.), $70+$ at Pakowki Lake, Alberta, 2 August 1996 (W. W. Smith, pers. comm.), and 129 immature curlews northeast of Leader, Saskatchewan 29 July 1997 (A.R. Smith, pers. comm.).

Historically, the Long-billed Curlew could be seen in large flocks during migration over much of the continent ${ }^{2}$. Over-hunting, in the early part of the century, may have sharply reduced numbers of curlews, but today the continuing loss of breeding habitat may be the major obstacle to population growth. Nesting habitat requirements vary across their range but curlews prefer short grass with little or no shrub cover. Curlews formerly nested in western Manitoba and southeastern Saskatchewan but are considered extirpated, as a breeding species, in these areas. Most Canadian curlews now breed in southwestern Saskatchewan and southeastern Alberta. West of the Rockies, the range is restricted with the largest numbers in the Chilcotin-Cariboo area of central British Columbia.

The Long-billed Curlew has been given a "Vulnerable" status by the Committee on the Status of Endangered Wildlife in Canada (C.O.S.E.W.I.C.) mainly because of habitat loss due to agricultural practices ${ }^{4}$. Alberta includes the species on its Blue List of species which may be at risk, also indicating that data is limited ${ }^{1}$. Although curlews are difficult to census, the Canadian population is currently estimated at 6500 birds 5 . Typical "shorebird" surveys focus on wetlands, thus they seldom record curlews whose breeding habitat requirements do not include water ${ }^{9}$. The only standardized census technique currently used is the Breeding Bird Survey which has estimated an annual population decline in Canada of $1.2 \%$ from 1980 through $1996^{8}$. In 1995-96, curlews were reported on only eight Canadian BBS routes, all in Alberta, where that provincial population trend indicates a decline of $2.9 \%$ per year. Neither decline is statistically significant because of the small number of routes, but the species is declining in the eastern portion of its breeding range ${ }^{8}$.

Wintering data of Canadian curlews is totally lacking. The only banding recovery was a bird banded, 20 June 1941, near Rosebud, Alberta and recovered in April 1944, near Plainview, Texas (Bird Banding Office, Canadian Wildlife Service). Do all Canadian prairie curlews migrate to Texas or do a proportion winter in California? A review of the Christmas Bird Count data from 1987-1996, published in American Birds/Field-Notes (National Audubon Society, Washington, D. C.), showed a Texas/Gulf Coast wintering population of about 1,400-2,450 curlews, compared to a California total which fluctuated between 4,200 and 10,600 birds for the period. It must be noted that Christmas Bird Count data is unreliable for estimating population trends because data collection methods are not standardized and all potential wintering sites, including those in Latin American, are not covered.

Data on the Canadian population is currently being collected as a component of other projects, primarily by the Canadian Wildlife Service. These include a project of extra BBS survey coverage in Alberta and Saskatchewan to census endemic grassland species 
(B. Dale, pers. comm.). Adult curlews are banded at their nests during a Marbled Godwit, Willet and Long-billed Curlew study in the Brooks, Alberta area (C. Gratto-Trevor, pers. comm.). Participants in projects on other prairie species, such as the Loggerhead Shrike census, will be solicited to collect curlew information (B. Johns, pers. comm.).

Bird-watchers can help by recording ALL encounters with curlews and documenting information such as number of birds, age if possible, location (longitude/latitude), date, habitat type and behaviour (pairs, foraging, defending young). This information should be sent to:

Gerry Beyersbergen, Canadian Wildlife Service, \#200, 4999 - 98 Avenue NW, Edmonton, Alberta T6B $2 X 3$ or by email gerard.beyersbergen@ec.gc.ca.

\section{Acknowledgment}

We thank Cheri Gratto-Trevor and Brian Johns for constructive comments on an earlier draft of this note.

\section{Literature Cited}

1. ALBERTA ENVIRONMENTAL PROTECTION. 1996. The status of Alberta wildlife. Alberta Environmental Protection, Natural Resources Service, Edmonton. 41pp.

2. BENT, A.C. 1962. Life histories of North American shore birds. Dover Publications, New York. 412pp.

3. CAMPBELL, R.W., N.K. DAWE, I. MCTAGGART-COWAN, J.M. COOPER, G.W. KAISER, and M.C.E. MCNALL. 1990. The birds of British Columbia Vol. 2. Royal British Columbia Museum, Victoria and Canadian Wildlife Service. $636 \mathrm{pp}$.
4. DE SMET, K.D. 1992. Status report on the long-billed curlew (Numenius americanus) in Canada. Environment Canada, Ottawa. 29 pp.

5. MORRISON, R.I.G., A. BOURGET, R. BUTLER, H.L. DICKSON, C. GRATTO-TREVOR, P. HICKLIN, C. HYSLOP, AND R. K. ROSS. 1994. A preliminary assessment of the status of shorebird populations in Canada. Progress Notes No. 208, Environment Canada, Canadian Wildlife Service. 19 pp.

6. PINEL, H.W., W.W. SMITH, AND C.R. WERSHLER. 1991. Alberta birds 1971-1980 Vol. 1, Non-passerines. Natural history occasional paper no. 13, Provincial Museum of Alberta, Edmonton. 243pp.

7. RENAUD, W.E. 1980. The long-billed curlew in Saskatchewan: status and distribution. Blue Jay 38(4): 221-237.

8. SAUER, J.R., J.E. HINES, G. GOUGH, I. THOMAS, AND P.G. PETERJOHN. 1997. The North American breeding bird survey results and analysis version 96.4. Patuxent Wildlife Research Center, Laurel, Maryland.

9. SMITH, A.R. AND H.L. DICKSON. 1989. Prairie shorebird survey 1987. Environment Canada, Canadian Wildlife Service, Edmonton. 60pp. 